\title{
Article
}

\section{Contesting the Dublin Regulation: Refugees' and Migrants' Claims to Personhood and Rights in Germany}

\author{
Bhimji, Fazila
}

Available at http://clok.uclan.ac.uk/16905/

Bhimji, Fazila ORCID: 0000-0002-7234-852X (2016) Contesting the Dublin Regulation: Refugees' and Migrants' Claims to Personhood and Rights in Germany. Intersections East European Journal of Society and Politics, 2 (4). pp. 51-68. ISSN 2416-089X

It is advisable to refer to the publisher's version if you intend to cite from the work. 10.17356/ieejsp.v2i4.214

For more information about UCLan's research in this area go to http://www.uclan.ac.uk/researchgroups/ and search for <name of research Group>.

For information about Research generally at UCLan please go to http://www.uclan.ac.uk/research/

All outputs in CLoK are protected by Intellectual Property Rights law, including Copyright law. Copyright, IPR and Moral Rights for the works on this site are retained by the individual authors and/or other copyright owners. Terms and conditions for use of this material are defined in the policies page.

\section{CLoK}

Central Lancashire online Knowledge www.clok.uclan.ac.uk

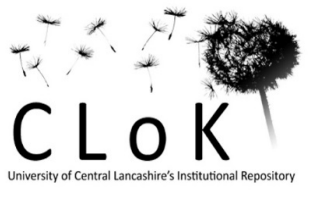


FAZILA BHIMUI *

\section{Contesting the Dublin Regulation: Refugees' and \\ Migrants' Claims to Persanhoud and Rights in \\ Germany}

Intersections. EEJSP

2(4): $51-68$.

DDI: $10.17356 /$ ieejsp.v2i4.214

http://intersections.tk.mta.hu

* [fbhimji@uclan.ac.uk] (University of Central Lancashire, United Kingdom)

\begin{abstract}
This study demonstrates how an EU law, Dublin 111, affects a heterogeneous group of refugees and migrants in Germany who first enter the EU through States such as Italy, Spain, or Hungary. The Dublin regulation allows refugees (with the exception of refugees from Syria) solely to make asylum-claims in the EU country through which they first enter and where they are initially fingerprinted. Therefore, if authorities find asylum-seekers' fingerprints in the database and can thus confirm that they have been in another EU Member State, then according to the Dublin regulation, they can be deported to the first country. The study illustrates the ways in which many refugees and migrants in Germany negotiate the Dublin law in differentiated ways, which subsequently enables them to claim their rights to personhood and dignity. More specifically, this study interrogates how some refugees are affected by the Dublin legislation and how they negotiate this law. This group of refugees have varied status in Germany some have claimed asylum, some fear imminent deportations, others have not claimed asylum within Germany, while there are others who are in the process of 'getting out of Dublin'. The study explores how these refugees with differing positions, status, and background negotiate their stay and personhood in Germany.
\end{abstract}




\section{Introduction}

This study demonstrates the ways in which refugees and migrants negotiate the Dublin legislation in Germany. Deportations to EU member states have been based on an agreement between the countries of the European Union (Dublin 111). According to the agreement, asylum-seekers are to be returned to the country of arrival in Europe and thus they have only one chance to claim asylum. Therefore, if authorities find an asylum-seeker's fingerprints in the database and can confirm that they have been in another EU member state, then according to the Dublin regulation, the asylum-seeker can be deported to the first country. This law works in conjunction with the EURODAC regulation, which provides for a fingerprint database to identify asylum-seekers.

As a consequence of the Dublin law, the status of the groups of refugees and migrants tends to vary. Some of the refugees and migrants have limited rights if they elect not to apply for asylum in Germany. While others include asylum-seekers who are waiting for decisions from immigration authorities and thus have access to basic rights such as food and accommodation, but at the same time fear deportation upon discovery of their fingerprints in the first EU member state. The study explores how this heterogeneous group of refugees and migrants with differing statuses who arrive from differing EU countries negotiate their position in Germany. This study also allows for a rethinking of migrant struggles - as struggles inclusive of and for personhood rather than simply as collective political actions. The study demonstrates that refugee and migrant activism needs to be recognized as a heterogeneous process. Refugees' resistance needs to be understood beyond politics since their acts, tactics and strategies and their struggles may additionally focus on attainment of sense of self, dignity and personhood.

Various thinkers relate the concept of personhood to notions of personal autonomy, self-hood, reflexivity and personal identity (Higgs and Gilleard, 2015). Ohlin (2005) notes that personhood and the necessary constituents, such as possessing consciousness determines moral status and in turn confers rights. Taylor (1992) connects personhood with the notion of moral agency. He argues that it is the very fact that people can experience guilt and shame and possess the capability of wanting to be other than what they are, form the very basis of personhood. Beverly Skeggs discusses the ways in which the abject inhabit personhood. Skeggs (2011) argues that personhood is found in the repeated attempts of the working-class to attach value through respectability such that their claims for value are not necessarily acquisitive but protests against moral denigration and misrecognition.

Legal scholar, Linda Bosniak's discussion on personhood is particularly useful for understanding non-citizens' acts for personhood, since she argues it is the law, which denies undocumented immigrants their sense of dignity. Bosniak argues that undocumented immigrants experience diminished personhood because of stringent laws and border controls and suggests that people need to strive for personhood because it is not automatically granted. She bases her argument on the fact that historically, large classes of human beings were denied recognition as equal - legal and moral persons -, treated as property, objects or otherwise less-than-persons. Bosniak, alluding specifically to undocumented immigrants, highlights three constitutional 
constructs that threaten significant evasions of personhood, which includes territoriality, peoplehood and enemy status. Bosniak argues, 'recognition of their status of personhood means that they are within the pale, within the law, for purpose of basic functioning in contemporary liberal society' (2011: 208). However, constitutional personhood is evaded and constrained for immigrants through the government's immigration enforcement authority of 'the border' and the 'ever present threat of deportation' (Bosniak, 2011). In this regard, I argue that refugees and migrants in Germany with limited and shifting statuses contest for recognition of personhood when the European Commission diminish their personhood through imposition of restrictive laws. Even more significantly, several of the refugees' struggles, which form part of this study, need to be understood to extend beyond collective contestations for territorial rights since they struggle in individual ways to be counted as a person.

The study addresses the following questions: How do the refugees and migrants entering from southern EU countries manage to continue to survive in Germany? Under which circumstances do they manage to stay? Does the Dublin law affect differing groups of migrants and refugees in different ways?

\section{Migrants and Mobilisation}

Mobilisation among refugees and migrants has been the focus of much scholarship. With prevailing policies resulting in the exclusion of legal migration, recent scholarship has attended to the ways in which refugees and migrants engage in every day acts of resistance. Immigrants often negotiate their everyday lives in their host states in the absence of formal citizenship. Nevertheless migrants and refugees without formal status are not left entirely without resources and in many cases seek out lawyers, agents, teachers, priests, journalists, activists and shopkeepers to help facilitate their migration process and to further help reverse their irregular status (Castle et al., 2012). In this regard, several scholars have demonstrated the ways in which regular and irregular refugees and migrants transform the idea of formal citizenship through their resistance (e.g. Isin, 2009; Anderson, 2010; Chimienti, 2011). Scholarship on refugees' mobilisation has understood their agency and activism as substantive citizenship such that migrants and refugees may continue to participate in polity, unions and religious networks even though they may not hold formal citizenship (e.g. Bhimji, 2010; Bhimji, 2014; Bhimji, 2016; Galvez, 2010; Moulin and Nyers, 2007; Rygiel, 2011; Isin, 2009; Lowry and Nyers, 2006). Migrants' struggles are generally understood in scholarship as collective claims for citizenship rights and inclusion rather than quests for individual dignity and respect. These struggles need not be regarded as mutually exclusive, but as this essay demonstrates that migrants' struggles against disrespect and dehumanisation needs further understanding as contestations against laws that deprive them of their basic rights.

Migrants have additionally been understood to engage in everyday acts of resistance or to 'subvert the rules of obedience of which Foucault speaks as they cross borders and prioritize their own basic needs and requirements' (De Genova, 2013). De Genova recognises migrants' struggles for a government of human mobility at large as well as state formation, sovereignty, citizenship, nationalism and racial formation. 
Scholars have also understood irregular and regular migrants as agents of political change and have understood their actions as 'ruptures' in the system (e.g. Balibar, 2004; Gordon, 2007; Isin, 2009; Nyers, 2008; McNevin, 2009). For example, Isin and Nielson introduce the notion of 'acts of citizenship' - a concept, which 'aims to disrupt habitus, create new possibilities, claim rights and impose obligations in emotionally charged tones' (p. 10). Drawing on this perspective of acts, Nyers argues that when non-citizens resist, they can be understood to be claim-making and rightstaking political beings.

Thus, much of this scholarship has understood immigrants' struggles and protests as quests for systemic changes, ruptures and participation in the polity. In this regard, migrants' activism is consequently understood in political collective terms, without much attention to the specificities of their individual struggles. In some cases, scholars have discussed migrants as idealized political subjects. However refugees' and migrants' everyday lives are lived out in complex ways and their acts of resistance need to be understood beyond the lens of citizenship (Chiementi and Solomos, 2011). There has been less discussion of refugees' and migrants' individual and differentiated struggles for dignity, respect, and humanity. Ellerman (2010) notes that even though resistance strategies are often part of a shared body of knowledge, resistance is usually exercised by individuals, rather than collectively which at the same moment is exercised towards short-term, rather than systemic change. In this regard, the notion of personhood with its constituents such as reflexivity, morality and respectability, provides a lens to understand heterogeneous and individual struggles, which do not necessarily always seek to challenge systemic structures or broader concerns of citizenship and state power but rather remain focused on the self.

Refugee activism has additionally been understood in categorical ways - those migrants who have legal status vs. those who are irregular (e.g. Galvez, 2010; Anderson, 2014). Migrants and refugees affected by the Dublin regulation cannot be easily categorised in this manner. Some of them may have refugee status in the first country with permission to visit the second country on a short-term basis, but they may not have rights to work. Others with fingerprints in a member state are based in the second country with decisions pending on their asylum cases. Yet other individuals with deportation notifications may be in the process of abiding six months so that they can 'get out of Dublin'. Thus, because of the complexities of refugees' and migrants' formal status, their differentiated struggles must be recognised in their full complexity.

\section{Methodology}

This essay is based on participant observation and interviews. I conducted 19 interviews in English and Urdu and held informal conversations with several people in languages such as French, Spanish, Urdu and English. Although I interviewed a smaller number of people formally, I did meet, speak and spend much time in Berlin and the surrounding areas with many more refugees from differing countries in less formal situations. The refugees had travelled into Germany through various routes such as Italy, Greece, Malta and Hungary. The refugees and migrants were a heterogeneous group in terms of their formal status, countries of origin, education 
level, and ages. Their countries of origin included Nigeria, Ghana, Pakistan and Syria. I conducted these interviews over a period of five months. The interview questions were open-ended and I focused on the ways in which the refugees were affected by the Dublin regulation and their everyday modes of survival since the aim of the study was to examine the specificities of their struggles and activism. Several of the interviewees mentioned that they were striving for dignity and respect and I asked them to provide examples and explain their understandings of these concepts.

The ages of the interviewees ranged between 20 and 41 years. Some of the refugees and migrants had attained formal education in their home country. The migrants also differed in terms of their status in Germany. Some refugees had claimed asylum, others had chosen deliberately not to claim asylum, while others had claimed asylum and had their cases rejected and were facing deportation. Among the people I spoke with, nine refugees had not applied for asylum in Germany, eight refugees were in the asylum process and two refugees' asylum claims had been rejected.

I had spent much time in Berlin as a researcher and as an activist over a period of two years prior to conducting research on this specific project. Therefore, I had the opportunity to repeatedly meet several of the migrants and had established friendships, which I maintained through social media. There were other refugees whom I met for the first time with the specific purpose to conduct interviews. I met the people I interviewed in demonstrations, meetings, theatre performances, and at their respective Heims (refugee shelters). Thus the data are based on participant observation and interviews. I employed a snowball technique such that the refugees and asylum-seekers introduced me to people who had their fingerprints taken in bordering European countries. Participant observation formed a significant aspect of my methodology. I volunteered twice a week for five weeks with a group, which helped find temporary residence for homeless refugees. Volunteers and political activists from this group met refugees on a daily basis in the evenings for two hours at a public square, 'Oranienplatz' in Berlin, and arranged temporary accommodation in activists' and residents' private homes as well as in emergency shelters. In this context, I met several people who were affected by the Dublin regulation and held interviews and informal conversations with them. I attended public meetings, demonstrations, and discussion sessions followed by theatre and screening events. In these spaces, several individuals offered personal accounts of how the Dublin regulation had had an impact on them. I had further discussions with human rights lawyers as well as German activists in order to gain further clarification about the Dublin law. Finally, I consulted various reports and websites, which explained the law in accessible terminology. De Genova (2002) contends the need for scholarship related to undocumented immigrants and refugees to deploy ethnographic methods or other qualitative research techniques to elicit the perspectives and experiences of undocumented refugees themselves, or to evoke the kinds of densely descriptive and textured interpretive representations of everyday life that sociocultural anthropologists tend to relish'. Hence, by employing a qualitative and ethnographic methodology, this study aims to contribute to scholarship relating to refugees and migrants whose legal statuses are not clearly defined. 


\section{Differentiated Status in Germany}

Refugees and migrants who arrived in Germany from the Southern European states had varied statuses, which shifted over a period of time. Consequently, their experiences within the EU states tended to differ over time. For example, the refugees and migrants who possessed 'Italian documents' decided to apply for asylum or simply tried to survive in Germany without asylum status. These refugees already had documents in one EU country and they understood that they would not be eligible to claim asylum in Germany. However, many of these refugees and migrants found themselves on the streets or in shelters. These refugees and migrants were allowed to travel within the Schengen states, but were not allowed to work outside the first EU member state that they had entered. Thus, once in Germany, the refugees and migrants experienced a shift in their legal status and lost their rights to work. For example, Fifi who came to Germany with 'Italian papers' decided not to apply for asylum in Germany. He told me, 'if I apply for asylum then most likely at the end of asylum they will tell me to return to Italy'. Alice Bloch et al. (2011) argue, 'people move in and out of different status - some enter in an irregular way, regularise their status through the asylum system and then become undocumented when their asylum case is refused' (p. 1294). In this context, the refugees' status changed not only because their asylum case was refused, but also because they moved from one EU member state to another.

There were multiple reasons why people decided not to reside in the first EU country they entered and decided to come to Germany. Several of the refugees stated that they were unable to survive the economic situation and live a life of dignity in countries such as Italy or Spain or Hungary since they were unable to find employment. They stated that they were not provided with accommodation facilities and were consequently left to survive on the streets. Nevertheless, they struggled to survive in the country where their status was compromised.

While some refugees decided not to claim asylum in Germany and get what they described as 'small small jobs', find shelter through some networks, and pay minimum rent in shared housing, there were others who decided to apply for asylum. However, in such circumstances, the German courts would eventually detect their fingerprints and they would receive a letter of rejection. In the letter, the court asked the applicant to provide reasons for making claims in a second European state given that they already had an asylum claim in a member state. For example, Asad had spent only a day in Italy, but was fingerprinted and thus became ineligible for asylum in a second country. Nevertheless, he claimed asylum in Germany, which was unsuccessful. Refugees and migrants who had arrived in Germany from EU states strove to negotiate their positions in different ways. Upon arriving in Germany, they were forced to make several life altering decisions. They needed to decide whether to claim asylum and risk deportation, but to have the opportunity to eventually regularise their status or to simply find work and shelter and remain in Germany with limited rights and irregular status. Upon rejection of their asylum cases, they needed to decide whether they should resist deportation or simply to agree to return to the first country. Thus, it becomes useful to examine migrants' activism through the lens of personhood as explained by several thinkers as the concept relates to autonomy, 
reflexivity, moral agency and self-hood. The Dublin regulation affected refugees' and migrants' decision-making processes and subsequent actions in differing ways. Thus, because the law became instrumental in affecting their lives in differing ways, the refugees were compelled to resist and negotiate the law in differing and individual ways.

\section{Migrants and Refugees without Asylum Claims}

The group of refugees and migrants who did not claim asylum needed to independently seek food, shelter and work, but these basic necessities were not always their end-goals since they spoke of attainment of dignity and humanity. The following sections demonstrate these different processes of struggles for basic rights and personhood.

\section{Seeking Housing, Health and Dignity}

Several of the refugees and migrants without asylum encountered housing problems. They arrived in smaller towns, but decided to move to Berlin to further their survival chances. Several refugees were forced to seek help from charity groups such as Caritas, but those who sought assistance from such groups did not understand this to be a long term-solution. The refugees realised that many of the people who lived in charity housing suffered from substance dependencies and mental health problems and the refugees and migrants who found themselves in the midst of such conflicts felt decidedly uncomfortable.

Sylvia of Nigerian origin who was forced to leave Libya with her two children for Italy recounted her situation. In Italy, she had worked as a hairdresser for several years. When the economy declined, she decided to come to Germany. When she came to Germany, she went to Caritas with her two children. However, she was only able to stay there for three days since she did not feel at ease there and ultimately became homeless. She realised that she could not possibly live on the streets because children were not permitted to reside on the streets. Fearing separation from her children, she sought help from activists. As she stated:

I went to Oranienplatz. I met some powerful women who were supporting refugees. They took me to the occupied school where I lived with my two kids. When I was there I participated in political actions and demonstrations until the day of the eviction.

Thus, many of the refugees who did not seek asylum tried to find support among German activists who helped organise temporary accommodation either in their private homes, shelters or spaces of activism. When they were unable to find spaces with residents in Berlin, the activists often sent them to emergency homeless shelters. However, the conditions in these shelters were very difficult. They were only allowed to stay overnight and were forced to leave early in the morning. Subsequently, they had to put in a fresh request for accommodation on the following day, travel back to the shelter, and pay an extra day of public transport fares. The refugees encountered 
much racism from the authorities managing these shelters. The managers conveyed an unfriendly demeanour and often directed the people to apply for asylum - thus treating them with little dignity and respect. Many of the refugees found it difficult to reside in these shelters but did so because they had no options. As many of them stated, 'well we have to sleep somewhere...we cannot sleep on the streets'. The refugees and migrants spoke favourably of their experience in private accommodation since they believed that they were respected in such situations. However, such accommodation did not always help to provide a long-term solution. Many of them strove towards and succeeded in finding a shared housing situation over a longer period of time since sharing housing in this way seemingly restored their sense of dignity and personhood. As Skeggs demonstrates in her study that working class women 'spent enormous time attempting to attach value to themselves to defend against devaluation, through the performance of respectability' (p. 8). When refugees resisted living in inappropriate conditions and sought to find appropriate and respectable living spaces, they arguably resisted denigration, through their negotiations and strategies.

Several of the refugees stated that sharing living space with hosts in this manner allowed them to integrate into the wider society since the people whom they lived with provided them with a sense of inclusion. Yasir, who had resided and lived in Manchester, U.K. for six months and worked as a security guard, stated that he felt particularly comfortable in Berlin because 'people here include refugees in their daily lives and social activities'. He said that during his stay in Manchester,

'I realised that the city was very segregated and that the English people did not even enter into conversation with me let alone invite me into their houses to live with them. But even though it was easier to find work in England for me, I felt more comfortable in Berlin since it was a relatively more open city where I lived with German activists and also participated in local refugee struggles. I also believed I had a better chance of eventually gaining formal citizenship status in Germany and thereby I stood a better chance of acquiring social status within a wider society.

As Bosniak puts it, people need to strive for personhood because it is not automatically granted. The above accounts demonstrate that several of the refugees sought to acquire respect since the Dublin regulation denied their chances of living in better circumstances. Yasir derived his sense of self through participating in refugee struggles together with German activists and feeling part of society. The actual State ceases to be significant for him and it is his interactions with members of the larger society which he finds more valuable. Thus, refugees value and prioritise their struggles in individual ways - but they demonstrate evidence of autonomy, selfreflexivity and quests for dignity.

Several studies have defined migrant activism through forms of struggles, which focus on regularising their status within the State (Nyers, 2008). However, such struggles for personhood cannot be solely understood as struggles between the state and the migrants nor can these acts be understood to disrupt the habitus, because to seek appropriate housing and to make connections with the wider society is to 
normalise one's life. Furthermore, actions of refugees and migrants under the Dublin law, need to be also regarded as individual contestations for personhood since it is this law, which makes it difficult for them to live a life of dignity. For example, Sylvia, who was initially staying at a refugee-occupied school, and who had not claimed asylum in Germany displayed much resistance. When the City Councillor of Kreuzberg did not provided her with an Ausweis (identification card), which would have allowed her to relocate to an assigned hostel or refugee Heim she contested this decision:

After much negotiation with the City Councillor, I approached his assistant security man and said, 'sir if Panhoff doesn't help me move from the school, then I will move into his house with my bag and my children. So then he will have to explain to his wife, how he knows a woman with two children?' In the end I had the card and was able to move to the Heim like the others.

Thus Sylvia struggled to live in dignity. She was homeless at one stage but she then managed to find shelter at an occupied school - which she found difficult to stay in because of constant police raids. Subsequently, she was able to move into refugee accommodation and became eligible to stay independently with her children. However, in the absence of Dublin law restrictions, she would have qualified to apply for housing in Germany upon arrival.

What is of significance here is that not all refugees and migrants resisted in a uniform manner but they all struggled for a life with dignity. They refused to stay in situations, which caused them distress and where their personhood remained threatened. For example, Sylvia participated in collective protests for a certain duration, but later she contested the Dublin legislation at an individual level, such that it enabled her to move forward with her particular case and she eventually obtained the rights to an individual apartment with her children. Similarly, for Yasir, maintaining his sense of self, gained priority over material concerns since he refused to continue to stay in Manchester even though he had a steady source of income there. For refugees, the notion of seeking shared housing in Berlin with activists needs to be understood as acts of preservation of dignity since they refused to stay without support on the streets of southern European states, which were affected in dire ways by the economic crisis. Rygiel (2011) recognises the ability of migrants to enact themselves as citizens by making claims to have presence within a social space, whether in the city proper, or in other global spaces, including that of the camp. However, arguably, for the refugees who formed part of this study, the state and citizenship had less significance in their everyday lives.

In addition to housing concerns, refugees and migrants did not have access to medical care unless it was an acute emergency. When they suffered ailments, they could only go to the Apotheke (pharmacy), describe their conditions to the pharmacist and hope to get the adequate medicine. In this regard, the refugees strove to access medicine on individual basis.

The refugees understood this situation as discriminatory since the 'citizens' with documents were eligible for health care. Although there was not an EU member state that specifically prohibited health care access, publicly subsidised care was not guaranteed across the region and undocumented immigrants were more likely to use 
NGO clinics or emergency systems and were generally unable to pay medical fees (LeVoy and Geddie, 2010). In such situations, refugees and migrants who arrived from a first country - many of them with refugee status in the first EU member state did not possess an EU health insurance card and thus depended on pharmacists or NGO clinics to provide them with the correct treatment.

Much scholarship has discussed how undocumented immigrants demonstrate the dire conditions they encounter when they lack formal status as their protection under international law is limited in a given state (e.g. LeVoy and Geddie, 2010; Bloch et al., 2011). Thus, the refugees and migrants had legal status in one EU member state, but needed to struggle for basic rights such as healthcare and housing, which they equated with a dignified way of life, in another EU state. As Omar stated, which echoed the voice of many refugees and immigrants, "we can only compare ourselves to Italians and Spanish who could elect to leave their own countries in favour of a better economic situation within the EU'. As Bosniak argues that undocumented immigrants experience diminished personhood because of stringent laws and border controls. The denial of health care to immigrants and refugees arriving from EU member States supports Bosniak's constitutional construct that immigrants and refugees are treated 'less than persons within the pale'. Nevertheless, despite the regulation, many individuals sought to access the healthcare system in differing ways.

\section{Work and Personhood}

Refugees and migrants who came through EU member states struggled to find work since they were not permitted to work in an EU member state of their choice. The group of refugees and migrants who had not sought asylum struggled to sustain themselves. They were pushed into what they called 'black', 'light' or 'small small jobs'. The refugees and migrants often equated work with dignity. For example, Fifi expressed his thoughts to me in the following way:

I wake up in the middle of the night and ask why can't I find work? Why am I not allowed to work here? I don't do marijuana. I don't do crimes. Because of paper I cannot work. Because of paper I cannot get my life together. This is not peace in the world. I'm here because I'm in danger. And then people look at us in a bad way because we don't have much work.

Akbar told me that when he arrived in Germany, he immediately found work doing construction work. He gave the following account:

When I find work I see that people exploit me. Some pay me. Some don't. Simply because my papers are not valid here. I can work in Italy, but in Italy there is no work. I put leaflets into people's letterboxes and they employ me for 30 Euros per day. After that I started construction work. I get 5 Euros per hour and make about 40 to 50 Euros a day. But I used to give to charity when I lived in Pakistan. I do not have the same standard of living in Europe. 
Thus the above accounts demonstrate that refugees who had arrived from other EU member states struggled to find work. They believed that the economy in Germany was stronger than in Italy. Thus, the accounts and experiences demonstrate that the refugees' and migrants' persistent endeavours to find work needs to be understood in terms of individual material struggles as well as their struggles to be counted as a person when it was the law that threatened their dignity and respectability (Bosniak, 2011). In this connection, it was the Dublin law, which prohibited refugees and migrants from attaining formal work status. The refugees who could not apply for asylum in the affluent European state were saddled with low-paid precarious work. Consequently, rather than granting value to migrants, the Dublin regulation helped facilitate a richer western EU member state obtain cheap and flexible labour.

\section{Asylum Applicants and the Dublin Law}

Despite the Dublin law, migrants and refugees had decided to apply for asylum. Their positions differed somewhat from that of the people who did not apply for asylum. They did not immediately need to find work and shelter and resided in refugee accommodation and received state benefits.

Unlike the people who had not applied for asylum, the asylum-seekers had access to shelter, food, and healthcare, but many people elected to work. The policies with respect to right to work for asylum-seekers were rather complex and many asylum-seekers could not work or find Ausbildung (apprenticeships). Thus, Bosniak's argument that it is the State which constrains personhood through its' enforcement of particular laws becomes valid. For example, Aslam explained,

you very well know the situation of Pakistan, there is no electricity, there is the constant danger of bomb blasts, one doesn't even know when a person steps out of the house that he or she would be able to return home or die on the streets. And so I really need to work, live a dignified life and send money home. That is all I wish.

Munir, an asylum-seeker, who had his fingerprints recorded in the Italian embassy in Mozambique when he applied for a Schengen visa and who came to Germany after spending some time in Italy stated that he tried to put meaning in his life by selling flowers at the weekends in Berlin. He gave the following account:

I know that I am not allowed to work here. But it's like my own business. I am selling flowers. It's enjoyable work. My headache declines. And I am not hurting anyone else in the process. I meet people in this way. I get to chat to people. I feel chilled out then. The atmosphere changes. If I don't work then I think that I would go crazy in this way. Sometimes I go to Club SO36 in Kreuzberg to sell flowers. It's a very welcoming club and they play all kinds of music there. I really enjoy the atmosphere there. So I just want to work in the way that normal people work. I want to pay taxes to the German State. 
These accounts demonstrate that asylum-seekers struggled for fuller membership in the wider society, but at the same time their actions could not be understood as overt and collective resistance to State power. The State held minimum significance for these refugees, who were focused on their individual needs, which in some instances extended beyond acquisition of material gains. For Munir, it was not sufficient that he had a place to reside - his aim was to integrate and gain respect in the wider society through work and paying taxes. In this regard, even refugees and migrants, who had some legal status in Germany, desired respect vis-à-vis employment since the notion of work was tied to dignity and personhood. Scholarship has understood refugees' resistance claims for rights as political ruptures (Nyers, 2008). However, there has been less understanding of actions, which can be regarded as refugees' struggles for an improved self. Munir's act of selling flowers cannot be understood solely an act of citizenship since he did not aim to participate in a wider polity, nor did he aim to shift laws which denied basic working rights to individuals affected by the Dublin policy at a collective level.

\section{Resisting Deportation and Rights}

Following a period of six months, from the time of their deportation proceedings or the expiration of their visa, an asylum-seeker with fingerprints in another EU member state could not be deported from Germany and could become eligible to apply for permanent asylum if they managed to stay in the second country. However, in the first six months many refugees and migrants experience the ever present threat of deportation, thus 'diminishing their sense of personhood' (Bosniak, 2011).

Many asylum-seekers contested the Dublin regulation individually by resisting deportation. In several instances, refugees were taken to an airport and put on a plane. In such situations, they often refused to board the plane because they knew that ultimately the pilot made the final decision about refugees' flight out of the country. As Michael from Cameroon, told me that at the airport he simply refused to board the plane. He gave the following account:

I told them, 'I am not here to leave Germany but I am here to find a solution'. The flight was ready, but I said I don't want to go up. I simply refused and they couldn't use force. I then explained to them about the difficult situation in Cameroon. So, I came back to the Heim. But no one has come back for me yet. Then the police told me that I needed to come back again. Many people then advised me to leave the Heim, but I continued to stay there letting everyone know that I would not run. I said, 'I am not a thief so why should I hide or run? I will just wait here till Dublin is finished for me. If I can stay here for six months then I don't have to go back'.

Michael's refusal to get on board can be understood as an act of resistance against injustice. Walters (2015) understands resistance located within commercial vehicles as 'viapolitics', arguing that acts of struggle within vehicles and their routes will continue as long as regimes of migration control continue. Thus, Michael's anti-deportation resistance could be understood in political terms - against the conditions of the 
Dublin regulation and against regimes and migration policies. However, Michael did not participate in any collective action. He continued to strive for his dignity by continuing to stay at the Heim since he refused to be criminalised for his particular actions.

While some asylum-seekers resisted deportation at airports, there were others who simply tried to find networks, which helped them survive the six-month period. There were many who decided to resist deportation by leaving their Heim following a deportation notification. Ali who had arrived from Malta resisted his deportation by taking a train from Gissen to Berlin. Since he had participated in some of the refugee mobilisation in Berlin for a year, he had established networks in Berlin. When he received his letter notifying him about his deportation proceedings, he contacted these networks and found a room in privately shared accommodation. He explained, 'I stay in a small room which I share with three women. I come to Kotti Café every evening, talk to people and drink ginger and mint tea, which helps me. I don't smoke much anymore'. Similarly, Osman upon receiving a letter rejecting his asylum case immediately left his Heim, met German activists and requested accommodation in a private house. He received some assistance in this regard for a week and ultimately decided to return to Italy to renew his documents. There were several refugees with documents from Italy who followed a similar procedure, ensuring that their Italian documents would remain valid while they tried to carve out a living in Germany. In this regard, many would travel back and forth between Italy and Germany three to four times a year. Taylor explains personhood in terms of moral agency and contends that people select from a range of options to live their lives because they experience affective responses. Refugees and migrants who protest against deportations as described in the above accounts enacted moral agency since they refused to experience the moral consequences of deportation and elected to survive in extremely difficult circumstances. For example, Ali of Pakistani origin resisted deportation to Austria by deciding to come to Berlin, finding some networks, and participating in various political actions and demonstrations with refugee activists. Ali's fingerprints were recorded in Austria. However, he decided to apply for asylum in Germany. Unhappy with his living conditions in his refugee accommodation and fearing deportation following the rejection of his asylum application, he ultimately found residence in a former squat house in Berlin and lived in a community with German citizens. He stated his plan was to stay there for six months and then to reapply for asylum. In the meantime, he also worked 'black jobs' and managed to survive economically.

Zainab a woman who arrived with her family from Syria through Hungary at the time when the Dublin regulation applied to Syrians became ineligible to apply for a second time in Germany. However, she managed to receive church asylum for six months, which was also very difficult to obtain since there were very few churches, which actually did offer church asylum in Germany. Zainab explained that she had stayed under church protection under very difficult conditions. She was not allowed to leave the premises as and when she wished, was not allowed visitors, and thus suffered much isolation during this process. She was informed that the consequence of leaving the church grounds would result in police arrests followed by deportation to Hungary. She pointed out that she had little choice since the option was to either to be deported 
to Hungary and to face detention for illegally leaving and entering the country or to remain within the grounds of the church and ultimately 'get out of Dublin'. Zainab chose the latter option and selected church sanctuary.

These accounts demonstrate that many asylum-seekers whose cases were rejected found differing ways to tide over the six-month period to 'get out of Dublin'. Their accounts show that they resisted against deportations from Germany in fragmented ways. Although many of the asylum-seekers tended to 'act' upon receipt of the letters informing them about their deportation proceeding or questioning them about the validity application, they had managed to form social networks through collective activism prior to the receipt of these letters. It is these social networks that helped them with struggles for their rights. Thus, refugees' collective agency and actions must not be entirely disregarded, but at the same time individual and differentiated resistance for their rights and personhood need recognition. Their acts demonstrate that they all struggled for personhood since they refused to be deported and in the process resisted being criminalised, isolated, or being left without resources and means.

\section{Collective Actions and Personhood}

In addition to individual ways of resistance refugees participated in collective actions. These acts could be understood to be relatively overtly political and the people who participated in demonstrations were concerned about changes in laws, which put them in difficult positions. However, at the same time these refugees had concerns about being counted as a person and for equal respect. For example, after receiving the rejection letter from the German courts, Ismael joined a protest bus tour and the protest tent group in Berlin with the aim to contest the asylum-policy in Germany. However, within 18 months, the tents were dismantled and many of the refugees who were affected by the Dublin law were then allowed to stay temporarily in a hostel, but then they received eviction letters within six months of their relocation. Included in this group were some migrants and refugees who had arrived in Berlin directly from another EU member state. Although there were several political actions against the evictions, they did not succeed. Finally, several refugees occupied a church and ultimately received church protection. They received church sanctuary after members of the church and the refugees entered into a prolonged and deliberate discussion concerning the topic of accommodation. For more than six months this church group has been providing refugees with accommodation in the church's meeting offices as well as in various community housing projects. However, it was not an easy task. The 120 refugees were forced to relocate constantly between offices in churches and community housing. The refugees additionally received 5 Euros per day. Ismael like many other refugees ultimately became involved in a series of political actions. Even after receiving church accommodation, some of the refugees organised a 'We are still here...' demonstration in May 2015, and an arch symbolising the boat on the Mediterranean Sea was carried on the demonstration route. Ismael commented that he was happy to see many black people participate in the demonstration, 'because this demonstration is about refugees and if a demonstration is dominated by Europeans, then people ask where are the refugees'. 
What is significant here is that even at a collective level, the refugees were very focused on individual concerns such as housing and their presence, The refugees resisted sleeping on the streets or to be deported to the first country where they would potentially encounter ill conditions. In this regard, their collective actions must also be understood as claims to personhood and dignity. Linda Bosniak raises the following point: "The very fact that undocumented are here in itself entitles them to significant constitutional rights and recognition. The territoriality principle accords legal and ethical significance to 'hereness', appropriately focusing on the social fact of a person's presence rather than on the legal formality of status to anchor basic constitutional recognition' (p. 211). Thus, the demonstration with the banners and the symbolic arch demonstrated refugees' individual presence in Berlin in addition to their struggles for constitutional recognition.

There were also groups of refugees from Lampedusa, who were involved in self-mobilisation. These groups, 'Lampedusa in Berlin' and 'Lampedusa in Hamburg' collectively demanded recognition of their refugee status, the right to work and residence in Germany. With support from activists, they organised public meetings and protests. However, at the same time, apart from such collective actions, individual refugees who formed part of this group went to several church groups, theatre discussions and student organisations in Universities where they raised awareness about the Dublin regulation. They aimed to counter the adverse messages about refugees and asylum-seekers in the mainstream media. Nadir pointed out that it was important for him to speak to people directly rather than to the media:

We know who we are and the media do not. And people can respond directly. For example, this young school student aged thirteen was asking very intelligent questions. They told me that we are all equal and that not all people are bad. Many of these children are German citizens who have fathers and mothers from different countries such as Turkey so they also understand the situation.

Thus refugees and asylum-seekers self-mobilised in differentiated ways, because they participated in public spaces, public gatherings and theatre. Actions undertaken by refugees and migrants affected by Dublin regulation remained fragmented because the law affected them in varying ways and their strategies led to different results. In this regard, they were compelled to act in differing ways. Some refugees and migrants were more dependent on their social networks while others acted more independently, but nevertheless the accounts demonstrated that many strove for a sense of self and conveyed moral agency.

\section{Concluding Comments}

Drawing on the concept of personhood as expressed by several scholars and Bosniak's idea that there is no guarantee of personhood for undocumented immigrants in the pale this study has shown that for many refugees and migrants affected by the Dublin law, personhood remained at stake. Scholars of refugee and migrant activism contend that migrants collectively contest wide-ranging issues such State power, borders, and citizenship status (e.g. De Genova, 2013; Nyers, 2008; Chimienti and Solomos, 2011; Galvez, 2010). Several scholars have argued that it is through their collective activism and contestations of their spaces that non-citizens 
enact citizenship (Rygeil, 2011). The refugees who had entered through European Union member states such as Italy, Hungary and Spain and had decided to relocate to their preferred EU State such as Germany, decided to stay and respond to the restrictions imposed by the Dublin law in individual and varied ways. Several refugees participated in political actions, theatre groups, community events and discussion sessions with the hope of bringing change in the asylum laws and policies thus depicting moral agency. Many refugees aimed to negotiate the law at an individual level and focused on attainment of personhood and dignity. In this way, refugee activism cannot always be understood in terms of struggles for rights to citizenship and contestations of border regimes and power, but rather their actions need to be understood inclusive of, and for personhood. In this regard, non-citizens' migrant activism needs reconsideration since the laws do not only deny them access to formal citizenship but rather to a host of basic rights that are connected to an individual's sense of self and well-being. Struggles for citizenship may need reworking since personhood in many instances may overshadow broader concerns of migrants' formal citizenship and border contestations such that the latter, though significant, may not be as urgent.

\section{References}

Anderson, R. (2014) Time and the Migrant Other: European Border Controls and the Temporal Economics of Illegality. American Anthropologist, 116 (4): 795-809. DOI: https://doi.org/10.1111/aman.12148

Amayo-Castro, J. M. (2013) International Refugees and Irregular Migrants: Caught in the Mundane Shadow of Crisis. In M. K. Bulterman and W. J. M. van Genugten (eds.) Netherlands Yearbook of International Law, 44: 65-88.

DOI: https://doi.org/10.1007/978-94-6265-011-4_4

Balibar, E. (2000) What we owe to the Sans-Papiers. In Guenther, L. and C. Heesters (eds.) Social Insecurity. Toronto: Anansi: 42-43.

Baubock, R. (2003) Reinventing Urban Citizenship. Citizenship Studies, 7 (2): 139160. DOI: https://doi.org/10.1080/1362102032000065946

Bhimji, F. (2010) Struggles, Urban Citizenship and Belonging: The Experience of Undocumented Street Vendor and Food Truck Owners in Los Angeles. Urban Anthropology, 39 (4): 455-492. DOI: https://doi.org/10.2307/41291334

Bhimji, F. (2015) Collaborations and Performative Agency in Refugee Theatre in German Theatre. Journal of Immigrant and Refugee Studies, 14 (1): 83103. DOI: https://doi.org/10.1080/15562948.2015.1024813 83-103

Bhimji, F. (2016) Visibilities and the Politics of Space: Refugee Activism in Berlin. Journal of Immigrant and Refugee Studies, 14 (4): 432-450. DOI: https://doi.org/10.1080/15562948.2016.1145777

Bloch, A., Sigona, N. and R. Zetter (2011) Migration routes and strategies of young undocumented migrants in England: A qualitative perspective. Ethnic and Racial Studies, 34 (8): 1286-1302. DOI: https://doi.org/10.1080/01419870.2011.560276 
INTERSECTIONS. EAST EUROPEANJOURNAL OF SOCIETY AND POLITICS, 2 (4): 51-68.

BHIMII, F.: CONTESTING THE DUblin REgUlation: REFUGEES' AND MIGRANTS' ClaIMS TO PERSONHOOD AND RIGHTS IN GERMANY

Bosniak, L. (2011) Human Rights within one State: Dilemmas of Personhood in Liberal Constitutional Thought. In Dembour, M. B. and T. Kelly (eds.) Are Human Rights for Migrants.? Critical Reflections on the Status of Irregular Migrants in Europe and the United States. Abingdon: Routledge. 201-221. DOI: https://doi.org/10.4324/9780203813447

Castles, S., M., Arias Cubas, C., Kim, and D. Ozkul (2012) Irregular Migration: Causes, Patterns, and Strategies. In Omelaniuk, I. (ed.) Global Perspectives on Migration and Development. New York, NY: Springer. 117-151.

DOI: https://doi.org/10.1007/978-94-007-4110-2_9

Chimienti, M. and J. Solomos (2011) Social Movements of Irregular Migrants, Recognition, and Citizenship. Globalisations, 8 (3): 343-360.

DOI: https://doi.org/10.1080/14747731.2011.576854

De Genova, N. P. (2002) Migrant illegality and deportability in everyday life. Annual Review of Anthropology, 31: 419-447.

DOI: https://doi.org/10.1146/annurev.anthro.31.040402.085432

De Genova, N. P. (2013) Foucault, migrations and borders. A Forum by materiali foucaultiani Responses by Nicholas De Genova. materiali foucaultiani, 2 (3): 153177.

Ellermann, A. (2010) Undocumented Migrants and Resistance in the Liberal State. Politics \& Society, 38 (3): 408-429. DOI: https://doi.org/10.1177/0032329210373072

Galvez, A. (2010) Guadalupe in New York: Devotion and the Struggle for Citizenship Rights among Mexican Immigrants. New York, NY: New York University Press. DOI: https://doi.org/10.18574/nvu/9780814732144.001.0001

Grant, S. (2011) Irregular migration and frontier deaths: acknowledging a right to identity'. In Dembour MB, Kelly T. (eds.) In Dembour, M. B. and T. Kelly (eds.)


Migrants in Europe and the United States. Abingdon: Routledge. 48-70. DOI: https://doi.org/10.4324/9780203813447

Higgs, P. and C. Gilleard (2016) Interrogating personhood as dementia. Aging and Mental Health, 20 (8): 773-780.

DOI: https://doi.org/10.1080/13607863.2015.1118012

Isin, E. F. (2009) Citizenship in flux: the figure of the activist citizen. Subjectivity, 29: 367-388. DOI: https://doi.org/10.1057/sub.2009.25

LeVoy M. and E. Geddie (2010) Irregular Migration: Challenges, Limits and Remedies. Refugee Survey Quarterly, 28 (4): 87-113.

DOI: https://doi.org/10.1093/rsq/hdq010

McNevin, A. (2006) Political belonging in a neoliberal era: the struggle of the SansPapiers. Citizenship Studies, 10 (2): 135-151.

DOI: https://doi.org/10.1080/13621020600633051 
INTERSECTIONS. EAST EUROPEANJOURNAL OF SOCIETY AND POLITICS, 2 (4): 51-68.

BHimji, F.: CONTESTING THE DUblin REgulation: ReFugEeS' and MigRANTS' Claims to PERSONHOOD AND RIGHTS IN GERMANY

68

McNevin, A. (2009) Contesting citizenship: irregular migrants and strategic possibilities for political belonging. New Political Science, 31 (2): 163-181. DOI: https://doi.org/10.1080/07393140902872278

Moorhead, C. (2006) Human Cargo: A Journey among Refugees. New York, NY: Picador Press.

Moulin, C. and P. Nyers (2007) 'We live in a country of UNHCR' - Refugee protests and global political society. International political sociology, 1 (4): 356-372. DOI: https://doi.org/10.1111/j.1749-5687.2007.00026.x

Ohlin, J. D. (2005) Is the concept of the person necessary for human rights? Columbia Law Review, 105: 209-249.

Rygiel, K. (2011) Bordering solidarities: Migrant activism and the politics of movement and camps at Calais. Citizenship Studies, 15 (1): 1-19.

DOI: https://doi.org/10.1080/13621025.2011.534911

Skeggs, B. (2011) Imagining personhood differently: person value and autonomist working class value practices. The Sociological Review, 59 (3): 496-513. DOI: https://doi.org/10.1111/j.1467-954x.2011.02018.x

Taylor, C. (1992) Sources of the self: The making of the modern identity. Cambridge: Cambridge University Press.

Walters, W. (2015) On the Road with Michel Foucault: Migration, Deportation and Viapolitics. In Fuggle, S., Y. Lanci and M. Tazzioli (eds.) Foucault and the History of Our Present. Basingstoke: Palgrave Macmillan. 94-110. DOI: https://doi.org/10.1057/9781137385925_7 